\title{
MY MILKMAN'S PASSAGE OF REMORSE THROUGH MILKWEED
}

Gene Tanta

When my porch's porch got licked by the light of night

and you didn't show up

what did I have to say? Locate

the milkweed, or

you have gone, or

you have what the fire rehearses.

The cold press of precedence as the hot ground between your legs.

You have always known a bridge as somebody's form of ambition.

I have my hands in the blood

and fun of innards from my milkman's passage of remorse

through milkweed. In the mirror you see persons and things

open winter as the sharpest thing you know.

Who you can't betray is dead.

You die of want, of nothing more and nothing.

Milkweed, with its resolve of arch

of crow to vowel got teased and parts the world

as a pea. My milkweed writes a past

of eaves' droppings as I am being asked questions.

A heavy coat, a heavy lunch, a washing off of other ways.

Milkweed loves its milkman and the milkman loves his milkweed.

For every time you're before a step, for every time

you're loud with numbers,

for every time you've stood on your head

perceive this hollow organ's structure, this hearse of common

talk the heart. 
I push my day up a hill of days, my day pushes back, my day comes back to love me for what I am not. With unheld beliefs you beat a line until settled to a path a path, once on a path you'll remember the hill you're on and how steep it is with all that you can't help wanting.

What you can't hold will burn you like a hill of dryness.

I run for rum and voyage. I am your nightmare

I know I have inside of me. We joggle-joints, kiss

and slipping apart is prevented. Worse,

it's the nightmare's seed come to muster. I'll find myself saying good-bye to your hello with every kiss

our lips shape wrong.

Yearning must be learned, said my milkman through my milkweed. 